\title{
Risk evaluation and exposure control of mineral dust containing free crystalline silica: a study case at a quarry in the Recife Metropolitan Area
}

\author{
Lira, Mario, Kohlman Rabbani, E. , Barkokébas Junior, Beda, Lago, Eliane \\ Civil Engineering Postgraduate Program, University of Pernambuco, Brazil
}

\begin{abstract}
During the production of aggregates at quarry sites, elevated quantities of micro-particulate mineral dust are produced in all stages of the process. This dust contains appreciable amounts of free crystalline silica in a variety of forms which, if maintained suspended in the air in the work environment, expose the workers to the risk of developing occupational silicosis, which causes reduced ability to work and potential shortening of lifespan. This study was conducted to qualitatively and quantitatively evaluate workers' exposure to mineral dust containing free crystalline silica at a midsized quarry in the Recife metropolitan area, in the State of Pernambuco. It involved evaluation of the industrial process, collection and analysis of representative dust samples, and interviews with the management team of the company with the intent to assess the compliance of the company with Regulatory Standard (NR) 22 - Occupational safety and health in mining. In order to assist the company in managing risks related to dust exposure, three protocols were developed, implemented and made available, the first based on NR 22 , from which the company was also given an economic safety indicator, the second based on the recommendations and requirements of Fundacentro to implement a Respiratory Protection Program and, finally, an assessment protocol with respect to the guidelines of the International Labor Organization to implement a health and safety management system. This study also showed the inadequacy of the formula for calculating tolerance limits in Brazilian legislation when compared with the more strict internationally accepted control parameters. From the laboratory results, unhealthy conditions at the quarry site were confirmed and technical and administrative measures were suggested to reduce and control dust exposure at acceptable levels, such as the implementation of an occupational health and safety management system, integrated with other management systems. From these assessments it is hoped that the proposals can assist the company in developing mechanisms for management and control of dust exposure risks that may improve environmental quality and the well-being of workers.
\end{abstract}

Keywords: Mining safety, occupational health, chemical hazard, mineral dust, quarry, free crystalline silica.

\section{Free crystallized Silica and Occupational Silicosis}

Many industrial activities, including the extraction and processing of rocks, handle materials containing mineral substances with some percentage of silicon dioxide, $\mathrm{SiO}_{2}$, known generically as quartz, but in fact, a mixture of quartz, cristobalite, tridymite and amorphous silica (in form non-crystallized form), the first one with great potential to cause fibrosis of lung tissues [1].

\footnotetext{
* Corresponding authors: mariolira13@gmail.com, emilialsht@poli.br, bedalsht@poli.br, elianelsht@poli.br
}

The origin of occupational silicosis, a silent disease and the oldest of known occupational diseases, directly depends on the concentration of free crystalline silica present in inhaled dust, the shape and size of quartz crystals in breathable fraction which enter the respiratory tract, and the duration of exposure [2].

Generally, larger particles, with diameters up to $100 \mu \mathrm{m}$, comprise the inhalable fraction of dust. As illustrated in Figure 1, they are retained in the upper respiratory tract and are responsible only for allergic reactions at this level. Particles with average dimensions smaller than $25 \mu \mathrm{m}$ make up the thoracic fraction, and are retained at the level of the trachea and bronchi. Finally, particles smaller than $10 \mu \mathrm{m}$, which 
comprise the breathable fraction, reach the regions beyond the bronchi, freely entering the areas of gas exchange in the lungs, causing the formation of fibrous tissue, originated from inflammation that causes tissue scarring.

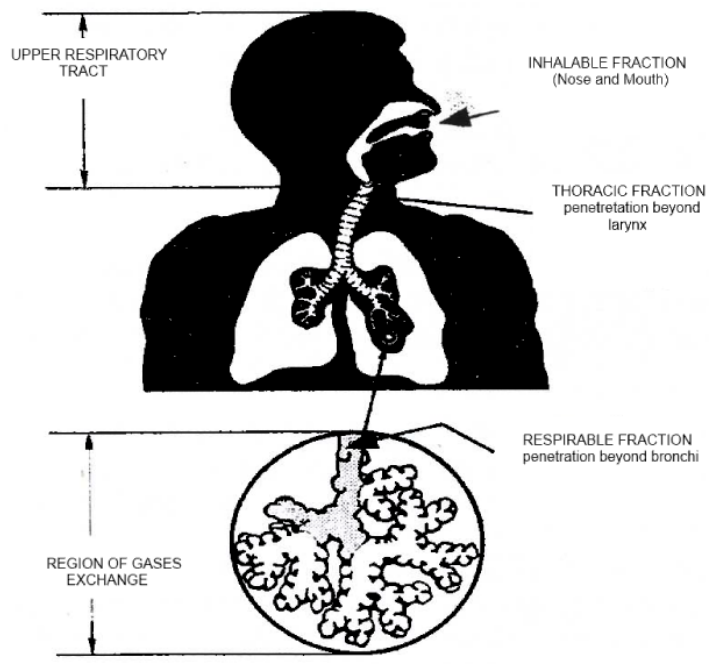

Figure 1 - Location of particle deposition in the respiratory system. Adapted from Phalen (1985) apud Martins [14]

In addendum, silicosis is often associated with other infections, such as silicotuberculosis, and generally accompanied by cardiac complications and potentially malignant tumors due to the carcinogenicity of free silica, as reported in published studies by the International Agency for Research on CancerIARC of the World Health Organization [3].

The disease, called "silicosis" by Visconti, was recognized in the year 1870, when it was acquired by workers in mines and quarries. Nowadays it is still prevalent as one of the most important among the pneumoconiosis [4]. This status is due to its condition as an incurable disease that progresses slowly and painfully until the worker's death, even after his removal from the unhealthy work environment.

In Brazil, the Regulatory Standard NR 15Unhealthy Activities and Operations, defines the activities, operations, and unsanitary agents, and their tolerance limits (LT), recognized as the minimum or maximum concentration or strength, depending on the nature and duration of exposure to the agent, that will not damage the health of the worker during his working life. Therefore, the workers' exposures to environmental conditions outside the limits of tolerance determine an unhealthy work condition that can cause diseases. This Regulatory Standard, as amended by Ordinance MTB No. 3.214, June 8, 1978, and updated by Ordinance MTE No. 43, March 11, 2008, establishes, in its Annex 12 - Tolerance Limits for Mineral Dust, occupational exposure limits for asbestos, manganese and its compounds, and free crystalline silica contained in the breathable fraction of mineral dust, whose tolerance limit is commonly represented by Eq.1, for a 48-hour work week:

$$
\mathrm{LT}=\frac{\mathrm{g}}{\% \text { de quartz o }+2} \mathrm{mg} / \mathrm{m}^{3}
$$

For the purposes of these limits, NR 15 considers the percentage of quartz concentrations as determined from the portion that passes through a selector filter with retention capacity having dimensions less than 10 micrometers for breathable particulates [5].

\section{Methodology}

This main objective of this study was to identify qualitatively and quantitatively the exposure of workers at a quarry to the breathable fraction mineral dust containing free crystalline silica in concentrations that may cause damage to the respiratory system, such as occupational silicosis [6].

In addition to the specific goals of this study, objectives were established to review the company's management as to its compliance with the legal guidelines regarding occupational health and safety:

- Perform a preliminary risk analysis at the company under study;

- Assess the compliance of the company with the requirements of national legislation, particularly in relation to Regulatory Standard NR22 - Occupational Health and Safety in Mining for specific items regarding open cast mining;

- Calculate the economic indicator of corporate occupational security, or passive occupational safety, determining an initial checkpoint as a reference for monitoring the scope of the measures to be implemented in accordance with NR 22 ;

- Diagnose the compliance of the company with the guidelines contained in Fundacentro's Respiratory Protection Program;

- Assess the compliance of the company with regard to the deployment of an occupational safety and health management system, in accordance with the guidelines of the International Labor Organization; 
- Finally, from the assessment of existing risk control systems and from the environmental working conditions, suggest the adoption of administrative measures and techniques, to eliminate, isolate, or reduce risk exposure.

This case study was conducted during the period from March to November of 2009, initially involving the study of industrial processes and the risks associated with activities and processes. Through use of the preliminary risk analysis (APR) methodology, through analysis of workplaces and activities performed, and through information obtained from the employees themselves about the potential hazards that exist for each task or function, as well as the risk control measures adopted, it was possible to choose sample collection points according to Occupational Hygiene Standard - NHO 08: Collecting Solid Particulate Matter Suspended in the Air of Work Environments [7].

The samples collected were analyzed to determine the concentration of breathable dust. The analytical method used was the NIOSH 0600 - Gravimetric analysis for Breathable Particles, as determined in the Occupational Hygiene Standard - NHO 03: Gravimetric Analysis of Solid Aerosols Collected on Filters and Membranes [8]; [9].

To quantify the percentage of silica contained in the collected samples, they were analyzed according to the NIOSH 7602 - Crystallized Silica by Infrared Radiation method [10].

To assess the company's level of compliance with Brazilian standards of occupational safety, surveys were developed and conducted with the operation manage, the maintenance manager, and the occupational safety manager. The surveys were in the format of a check list, as suggested by Barkokébas Junior [11], and widely used as a tool for evaluation by several researchers in various areas of occupational safety and hygiene; see for example Kohlman Rabbani, et al. [12], Lago, et al. [13], Martins [14] and Véras [15].

The checklists were prepared by compiling relevant issues from the items of NR 22-Occupational Safety and Health in Mining, aiming to obtaining responses that either comply (CO), do not comply (NC), or are not applicable (NA). The occupational safety economic indicator model was also calcued from the same NR 22 as well as NR 28 - Supervision and Penalties, as proposed by Barkokébas Junior [11] whose calculation consists of the sum of the values relating to the possible financial penalties from the
Ministry of Labor and Employment - MTE, for items not in compliance.

In addition, two other checklists were drawn up to evaluate the level of compliance of the company. The first followed Fundacentro's Respiratory Protection Program - PPR and was based on the list of requirements for the deployment of a respiratory protection program established by standards of the Ministry of Labor and Employment - IN n1, from $4 / 11 / 1994$, which obliges employers to install and monitor a respiratory protection program contained in the Respiratory Protection Program: Recommendations, Selection and Use of Respirators - PPR, from Fundacentro [16]. The second protocol was based on the guidelines of the International Labor Organization - ILO, applicable to occupational safety and health management systems and contained in the ILO publication as translated and edited in Brazil by Fundacentro, under the title "Guidelines on Occupational Safety and Health Management Systems" [17].

\section{Results}

Regarding the compliance of the company with Brazilian legislation and national and international standards regarding the risk of exposure to mineral dusts containing free crystalline silica, referencing principally Regulatory Standard NR-22 - Occupational Health and Safety in Mining, along with items from Regulatory Standard NR-15 - Unhealthy Activities and Operations, and with laboratory confirmation of the presence of free crystalline silica at levels exceeding the tolerance limit, mining activity is shown to be an unhealthy activity. Occupational hazard management must still obey Regulatory Standard NR-9 - Environmental Hazard Protection Program, which stipulates that companies must initiate preventive actions when the concentrations of aggressive agents exceed the action level, or $50 \%$ of the calculated tolerance limit.

For the purpose of assessing free crystalline silica exposure hazards, qualitative assessments were carried out for the job operations: primary drilling and hammer operator, primary crushing and transportation of rocks, general assistant, and general supervisor. The processes of secondary and tertiary crushing, even being conducted at a distance and at indoor sites, were also analyzed due to the high level of environmental contamination and consequent exposure of workers from other sectors, caused by the distribution of dust across the quarry's environment by local winds. The results of this analysis contributed to the 
choice of jobs from which samples of breathable dust were taken in order to perform the quantitative analysis of quartz.

\subsection{NR 15 standard parameters}

The quantitative risk obtained considered the data contained in Table 1. The first column of data contains the values for breathable dust-RD, obtained from the samples analyzed and called M1 to M12. In the second data column, the computed values for the tolerances in accordance with the Regulatory Standard NR-15 can be found, valid for 48 hours of expo- sure. The third column shows these values recalculated for 53 hours of work, obtained from the Brief \& Scala correction formula according to Gruenzner [18], which corresponds to the actual work week at the company. The last two columns list the risk factor values, calculated by the ratio between the existing levels of breathable dust and the tolerance limits calculated, respectively, by NR 15, the LT, and the corrected $\mathrm{LTC}$.

Table 1

NR 15 standard analysis 1

\begin{tabular}{|c|c|c|c|c|c|c|}
\hline Sample & Activity & $\begin{array}{l}\text { Breathable } \\
\text { Dust } \\
\left(\mathrm{mg} / \mathrm{m}^{3}\right)\end{array}$ & $\begin{array}{c}\text { Tolerance } \\
\text { limit }(\mathrm{mg} / \mathrm{m} 3) \\
\text { NR } 15 \\
48 \text { hours }\end{array}$ & $\begin{array}{c}\text { Tolerance } \\
\text { limit }(\mathrm{mg} / \mathrm{m} 3) \\
\text { Corrected for } 53 \\
\text { hours }\end{array}$ & $\begin{array}{c}\text { Risk } \\
\text { Factor } \\
\text { NR } 15\end{array}$ & $\begin{array}{l}\text { Corrected Risk } \\
\text { Factor }\end{array}$ \\
\hline & & RD & LT & LTC & RD/LT & RD/LTC \\
\hline 20090638 & $\begin{array}{l}\text { M1- Primary crusher } \\
\text { operator (a) }\end{array}$ & 6.611 & 0.307 & 0.260 & 21.53 & 25.42 \\
\hline 20090685 & $\begin{array}{l}\text { M2-Primary crusher } \\
\text { assistant }\end{array}$ & 2.531 & 0.273 & 0.231 & 9.27 & 10.95 \\
\hline 20090707 & M3- General supervisor & 0.797 & 0.307 & 0.260 & 2.60 & 3.06 \\
\hline 20090701 & M4- Truck driver 1 & 0.795 & 0.325 & 0.275 & 2.44 & 2.89 \\
\hline 20090593 & $\begin{array}{l}\text { M5- Primary drilling } \\
\text { operator }\end{array}$ & 2.065 & 0.298 & 0.253 & 6.93 & 8.16 \\
\hline 20090688 & $\begin{array}{l}\text { M6- Primary drilling } \\
\text { assistant }\end{array}$ & 1.297 & 0.252 & 0.214 & 5.14 & 5.14 \\
\hline 20090695 & M7-Hammer 1 & 1.270 & 0.264 & 0.224 & 4.81 & 5.67 \\
\hline 20090705 & M8- Hammer 2 & 1.036 & 0.350 & 0.297 & 2.96 & 3.49 \\
\hline 20090692 & $\begin{array}{l}\text { M9-Primary crusher } \\
\text { operator (b) }\end{array}$ & 0.965 & 0.252 & 0.214 & 3.83 & 4.51 \\
\hline 20090689 & M10-Truck driver 2 & 0.415 & 0.419 & 0.355 & 0.99 & 1.17 \\
\hline 20090645 & $\begin{array}{l}\text { M11-Tertiary crusher } \\
\text { operator }\end{array}$ & 0.204 & 0.388 & 0.329 & 0.53 & 0.62 \\
\hline 20090706 & M12-General assistant & 1.112 & 0.253 & 0.214 & 4.40 & 5.20 \\
\hline
\end{tabular}

The ratio between the levels of breathable dust and the tolerance limits, called here the risk factor, indicates the intensity of the risk, revealing how far it is above calculated tolerance limits and confirms the diagnosis of unhealthy conditions in the company's environment, from mining to quarry.

Furthermore, risk factor clearly shows the efficiency of simple measures, as legislated, such as the adoption of locations and machines equipped with ambient control devices like air conditioning and air filtering. Finally, it provides a basis for the selection of personal protective equipment for workers to give them adequate respiratory protection.
From the results of quantitative analysis of quartz (RD), only sample M11 presented an exposure value below both tolerance limits, calculated (LT) and corrected for the work of 53 hours per week (LTC). However, the concentration found exceeds the action level advocated by NR 9 - Program for the Prevention of Environmental Hazards, which is greater than $50 \%$ of the calculated tolerance limit for this sample. This obligates the employer to adopt individual and collective measures to control risk, even if there are control measures deployed in this job.

The results obtained from the analysis of samples M4 and M10, corresponding to the truck driver, 
showed that the air conditioner used in the trucks reduces the level of exposure, but not sufficiently to offer adequate protection, highlighting the need for constant use of EPR (Respiratory protection equipment) for these functions. Samples M1 and M2, presenting risk factors greater than 10, suggest the adoption of masks with larger particle retention capacity, given that the PFF1 masks provided to all workers irrespective of their function, which are only $85 \%$ efficient, meet requirements only up to 10 times the measured risk intensity as recommended in the Respiratory Protection Manual of Fundacentro [16]. For the remaining functions, of very high risk factor values were found, confirming the inadequate health conditions in the quarry environment.

\subsection{ACGIH parameters}

ACGIH currently sets TLV-TWA at $0.025 \mathrm{mg} / \mathrm{m}^{3}$ for free crystalline silica - FCS, and at $3.0 \mathrm{mg} / \mathrm{m}^{3}$ for breathable mineral dust classified as PNOS (Particulates not otherwise regulated). In Table 2, the original values and those corrected for the company's work week are listed.

Table 2

TLV-TWA: Guideline values and Corrected values for 53 hours of work

\begin{tabular}{|c|c|}
\hline TLV-TWA / & TLV-TWA / CORRECTED VAL- \\
(40h) & UE (53h) \\
\hline $\begin{array}{c}\text { Quartz }=0.025 \\
\mathrm{mg} / \mathrm{m}^{3}\end{array}$ & $0.017 \mathrm{mg} / \mathrm{m}^{3}$ \\
\hline $\begin{array}{c}\text { PNOS }=3.0 \\
\mathrm{mg} / \mathrm{m}^{3}\end{array}$ & $2.03 \mathrm{mg} / \mathrm{m}^{3}$ \\
\hline
\end{tabular}

In Table 3, the risk factors are listed, representing how far actual exposure levels are above the internationally recognized occupational exposure limits for free crystalline silica and mineral dust.

In this table, the use of PNOS for breathable dust is only as a comparison based on the ACGIH suggestion of limits for exposure to mineral dust whose content is known but which do not have an applicable exposure limit (TLV), as well as where there is little data about its composition and its interaction with the aqueous fluid of the lung. The ACGIH, for the purposes of adopting control parameters and as a reference, considers that these insoluble or poorly soluble particles, even if they are assessed as biologically inert, can cause adverse effects from inhalation and therefore recommends that environmental concentrations must be maintained below $3.0 \mathrm{mg} / \mathrm{m}^{3}$ and considers that level as an occupational exposure limit [19].

All samples collected showed free crystalline silica, the most aggressive mineral dust agent, to be found at levels higher than the TLV-TWA occupational exposure limits.

In Table 3, the method of calculation of the RD/LEO and FCS/LEO ratios is similar to the calculation of the risk factor previously mentioned and consists of the relationship between the values found for free crystalline silica and the values of the TLVTWA corrected for 53 hours, and the relationship between the breathable dust values and its TLVTWA also corrected for the same amount of time. This assessment further strengthens the conclusion about the unhealthy quality of the activities performed in the quarry under study, because it does not reveal any conditions below the occupational exposure limit for silica.

Also, it is important to state that Brazilian law is extremely outdated, since it is based on parameters that are not observed internationally, dimensionally nor conceptually, and they do not validate the formula for calculating the tolerance limit of breathable dust as the formula to be used in Brazil. According to ACGIH, as shown in table 2, they believe that concentrations of mineral dust over $3.0 \mathrm{mg} / \mathrm{m}^{3}$ should not be accepted in industrial environments, but only as a suggestion, not an exposure limit. In addition, the more restrictive international laws advocate that environmental concentrations of free crystalline silica being held below an occupational exposure limit of $0.025 \mathrm{mg} / \mathrm{m}^{3}$ as the most important parameter in preventing silicosis.

\subsection{NR-22 standard analysis}

The collection of information relating to the compliance of the company with Regulatory Standard NR-22 was achieved by applying a questionnaire in the form of a check list, covering its key items, particularly those relating to the activity of open-pit mining. The responses to the form were given 
Table $\cdot$

Risk factors compared to occupational exposure limits from ACGIH, corrected for time at work

\begin{tabular}{|c|c|c|c|c|c|}
\hline \multirow[t]{2}{*}{ Sample } & \multirow[t]{2}{*}{ Activity } & $\begin{array}{c}\text { Breathable Dust } \\
L E O_{R D}: 2.03 \mathrm{mg} / \mathrm{m}^{3}\end{array}$ & \multirow{2}{*}{$\begin{array}{c}\text { Free Crystalline } \\
\text { Silica } \\
L_{E O_{s}}: 0.017 \mathrm{mg} / \mathrm{m}^{3} \\
\\
\text { FCS } \\
\end{array}$} & \multirow{2}{*}{\begin{tabular}{l}
\multicolumn{1}{c}{ Risk Factor } \\
RD/LEO \\
Corrected for 53 \\
hours \\
RD/LEO \\
\end{tabular}} & \multirow{2}{*}{$\begin{array}{c}\text { Risk Factor } \\
\begin{array}{c}\text { FCS/LEO } \\
\text { Corrected for } 53 \\
\text { hours }\end{array} \\
\text { FCS/LEO } \\
\end{array}$} \\
\hline & & RD & & & \\
\hline 20090638 & $\begin{array}{l}\text { M1- Primary crusher oper- } \\
\text { ator (a) }\end{array}$ & 6.611 & 1.589 & 3.25 & 93.75 \\
\hline 20090685 & $\begin{array}{l}\text { M2-Primary crusher assis- } \\
\text { tant }\end{array}$ & 2.531 & 0.692 & 1.24 & 40.83 \\
\hline 20090707 & M3- General supervisor & 0.797 & 0.192 & 0.39 & 11.33 \\
\hline 20090701 & M4- Truck driver 1 & 0.795 & 0.180 & 0.39 & 10.62 \\
\hline 20090593 & $\begin{array}{l}\text { M5- Primary drilling oper- } \\
\text { ator }\end{array}$ & 2.065 & 0.513 & 1.02 & 30.27 \\
\hline 20090688 & $\begin{array}{l}\text { M6- Primary drilling } \\
\text { assistant }\end{array}$ & 1.297 & 0.385 & 0.64 & 22.71 \\
\hline 20090695 & M7-Hammer 1 & 1.270 & 0.359 & 0.62 & 21.18 \\
\hline 20090705 & M8- Hammer 2 & 1.036 & 0.216 & 0.51 & 12.74 \\
\hline 20090692 & $\begin{array}{l}\text { M9-Primary crusher opera- } \\
\text { tor (b) }\end{array}$ & 0.965 & 0.287 & 0.47 & 16.93 \\
\hline 20090689 & M10-Truck driver 2 & 0.415 & 0.071 & 0.20 & 4.19 \\
\hline 20090645 & $\begin{array}{l}\text { M11-Tertiary crusher } \\
\text { operator }\end{array}$ & 0.204 & 0.038 & 0.10 & 2.24 \\
\hline 20090706 & M12-General assistant & 1.112 & 0.330 & 0.55 & 19.47 \\
\hline
\end{tabular}

by the Occupational Safety Engineer and by the Maintenance Engineer (Manager of maintenance) and resulted in 89 items in compliance (CO), 59 items not complying (NC), and 7 items not applicable, out of a total of 155 items. These results demonstrate the need to deploy, monitor, and record a minimal system for proper management of occupational health and safety, in complete accordance with the standard studied.

Among the items not complying - NC, annotated from the responses obtained in the interviews and confirmed by the observation of the industrial process, were found the non-observance of those items that govern the use of wet processes on drilling of rock or the presence of waste collection devices that prevent environmental release, as well as the use of water in insufficient quantities or discontinuously in the processes of crushing or transport. This contributed to the presence of large amounts of suspended dust in the mining and aggregates industry environment.

\subsection{Economic Indicator}

The economic indicator, calculated on the basis of non-compliance obtained in the previous checklist, and referenced to the minimum infringement values from standard NR 28 produced a total liability of $\mathrm{R} \$ 137,000.00$, which reveals the need for stringent investments with respect to this standard. It is important to note the fact that this monetary indicator should be used as a temporal indicator, with emphasis on its contribution to continuous improvement. It is a reference and a starting point of an occupational hazard control program.

\subsection{Fundacentro Respiratory Protection Program}

In assessing compliance with Fundacentro's Respiratory Protection Program, the company, despite providing respiratory masks and other individual protection equipment as specified in the risk management program - PGR, achieved a score of 5 items in compliance (CO), out of a total of at least 17 items, 
revealing 11 non-compliant $(\mathrm{NC})$, an elevated level of non-compliance.

In this check list, from the same interviewees, the lack of formal procedures or documentation regarding the choice of respirators or hazard control training and information actions was demonstrated. Responsibility for the release of respiratory protection equipment is held by an official of the warehouse upon request of maintenance management, in order to allow periodic weekly distribution to the workers.

The historical records of quantitative measurements of mineral dust, which contain significant quantities of free crystalline silica, are noted in the company's PGR, through their technical report of work environmental conditions - LTCAT, but are not accompanied by documentation concerning procedures, equipment, and methods of evaluation or legal reports issued by certified laboratories. The existing record of results regarding breathable dust appear unreliable because of the repetition of percentage of breathable dust at equal values for all activities, an impossible occurrence, as demonstrated by the actual results obtained from the analysis of samples in the field listed in Table 1.

\subsection{ILO guidelines}

The checklist, according to ILO guidelines for occupational safety and health management systemsSGSST, has also revealed an inadequate level of compliance at the company, demonstrating the need for investment in order to prepare for efficient occupational safety management. In this survey, 10 items were in compliance (CO) with the checklist and 54 items were not in compliance (NC), out of a total of 64 items evaluated. This reveals the need for formal records, training, communication, and the involvement of the company and its employees with a formal system that recognizes the risks and gives priority to occupational safety preventive actions, integrated with quality systems currently available or in development.

\section{Conclusion}

Based on the results obtained in the sample analysis in multiple company environments, this study confirms the unhealthy conditions regarding environmental concentrations of mineral dust containing hazardous levels of free crystalline silica, for all studied job functions. Despite being inevitable, according to the characteris- tics of the "raw material" and the industrial process, the risk of exposure to silica is potentially controllable through use of techniques or equipment with dust collectors as well as the use of individual protection equipment for greater efficiency, at minimum the $\mathrm{N} 95$ Mask with $95 \%$ efficiency, similar to PFF2 Mask in the Brazilian classification.

The study also highlighted the need for investments in the development of the compliance of the company with regard to Brazilian legislation on mining safety and with a committed management clearly and strongly involved with the concepts of occupational safety.

Continual training and the need for information about risk severity are a required priority and should assume that the risk of exposure to mineral dust is inevitable, but potentially reducible under appropriate control measures. In light of this fact, it should be inferred that these efforts must be undertaken, to reduce the exposure of workers and help preserve their respiratory systems, particularly through the development of a consistent respiratory protection program dedicated to choosing the best and most efficient respiratory protection equipment, implementing collective measures such as using machines equipped with dust collectors, and utilizing better and more efficient humidification systems.

Challenges necessary to the management and direction of the company are to incorporate in their Mission the commitment to safety for industrial operations as a way to increase the quality of results and the company's relationship with the various communities involved, considering the needs to invest in the deployment of an occupational safety and helth management system - SGSST, integrated with other enterprise management systems.

In the legal sphere, it is urgent to promote changes in Brazilian legislation to modernize and make them more efficient and rapid, assuming stricter and more modern parameters for hazard control, as are currently in use internationally.

It is hoped, therefore, that governments and companies recognize the relevance of the problem to the same extent that they recognize the economic importance of this industrial activity in the development of the country and promote prevention as a priority, so as to contribute to the advancement of the National Program for the Eradication of Silicosis - PNES, conducted by FUNDACENTRO. 


\section{References}

[1] T. M, Saliba. Manual prático de avaliação e controle de poeira e outros particulados - PPRA. São Paulo: LTR, $3^{a}$ ed. 2007.

[2] Manual Merck De Medicina. Diagnóstico e tratamento. 16 ed. São Paulo: Roca, 1995, 591 p

[3] International Agency for Research onCancer (iarc). Evaluation of carcinogenic risk to humans: silica, some silicates, coal dust and para-aramid fibrils. Monographs, vol. 68, Lyon, France. World Health Organization (WHO), 1997. Available at: http://inchem.org?documents/iarc/vol68/silica.html. Accessed on: $04 / 07 / 2009$.

[4] R.V, Santos. Silicose ocupacional: a face de uma pro-blemática social. São Paulo: LTR, 2000.

[5] Normas regulamentadoras do Ministério do Trabalho e Emprego. Available at: http://www.mte.gov.br/normas regulamentadoras. Accessed on: 03/01/2010.

[6] M, Lira. Avaliação e controle dos riscos relacionados à exposição à sílica livre cristalizada em uma pedreira da Região Metropolitana do Recife. Recife, PE. Monograph presented for Postgraduate degree in Work Safety Engineering Polytechnic School - University of Pernambuco, 2010, 177p.

[7] Fundação Jorge Duprat Figueiredo de Segurança e Medicina do Trabalho - Fundacentro. Coleta de material particulado sólido suspenso no ar de ambientes de trabalho. (Procedimento técnico). NHO-08. São Paulo, 2007. (Normas de Higiene Ocupacional).

[8] (FUNDACENTRO, 2001;) Fundação Jorge Duprat Figueiredo de Segurança e Medicina do Trabalho - Fundacentro. Análise gravimétrica de aerodispersóides coletados sobre filtros de membrana (Método de ensaio). NHO-03. São Paulo, 2001. 34 p.(Normas de Higiene Ocupacional).

[9] National Institute for Occupational Safety and Health - NIOSH Particulates not otherwise regulated. Method 0600, Issue 3, dated 15 January 1998 - Page 2 of 6. In: NIOSH Manual of analytical methods (NMAM $\mathbb{R}) .4^{\text {th }}$ ed. 2003. Available at: http://www.cdc.gov/niosh/docs/2003-154/pdfs/0600.pdf. Accessed on: 28/09/ 2009.

[10] National Institute for Occupational Safety and Health NIOSH. Silica, Crystalline, by IR. Method 7602, issue 3. In: NIOSH Manual of analytical methods (NMAM $\left.{ }^{\circledR}\right)$. 4th ed., 2003b. Available at: http://www.cdc.gov/niosh/docs/2003154/pdfs/7602.pdf. Accessed on: 28/09/ 2009.

[11] B, Barkokébas Junior; J. C, Véras; M. T. N, Cardoso; G. L, Cavalcanti; E. M. G, Lago. Diagnóstico de segurança e saúde no trabalho em empresa de construção civil no Estado de Pernambuco. In: XIII Congresso Nacional de Segurança e Medicina do Trabalho. São Paulo, 2004.

[12] E. R, Kohlman Rabbani; B. Barkokébas Júnior; E. M G.,Lago; A. R. B., Martins,; R. P, Almeida Filho. Characterization of the workers exposition to dust in road workmanships in the regularization phase and preparation of base and subcourse - study case. In: XXVIII Encontro Nacional de Engenharia de Produção - ENEGEP / XIV ICIEOM - International Conference on Industrial Engineering and Operation Man- agement, 2008, Rio de Janeiro. Anais... Rio de Janeiro: ABEPRO, 2008.

[13] E. M. G, Lago.; B, Barkokébas Junior; E. R., Kohlman Rabbani, J. C, Véras,.; T. R. F, Silva,. Indicadores de gestão de segurança em uma indústria de cimento. In: XXVIII Encontro Nacional de Engenharia de Produção.Anais... Rio de Janeiro-ABEPRO, 2008

[14] A. R. B, Martins. Characterization and evaluation of dust present in the construction sites of vertical buildings/Ana Rosa Bezerra Martins, Dissertation. Polytechnic School of University of Pernambuco - Pernambuco, 2009.

[15] J. C. Véras; B. Barkokébas Junior; L.B. Martins, Protocolo para análise de riscos de acidentes em obras na fase de estruturas. In: XXVI ENCONTRO NACIONAL DE ENGENHARIA DE PRODUÇÃO - ENEGEP, 2006. Anais... Fortaleza-ABEPRO, 2006.

[16] Fundação Jorge Duprat Figueiredo de Segurança e Medicina do Trabalho - Fundacentro. Programa de proteção respiratória (PPR) - Recomendações, seleção e uso de respiradores. São Paulo, Fundacentro, 2002.

[17] Fundação Jorge Duprat Figueiredo de Segurança e Medicina do Trabalho - Fundacentro. Diretrizes sobre Sistemas de Gestão da Segurança e Saúde no Trabalho. São Paulo, 2005.

[18] G. Gruenzner, Avaliação da poeira de sílica: um estudo de caso em uma pedreira na região metropolitana de São Paulo. São Paulo: Dissertação de mestrado da Escola Politécnica da Universidade de São Paulo, 2003, 93 p.

[19] American Conference of Governmental Industrial Hygienists (ACGIH). TLVs ${ }^{\circledR}$ e BEIs ${ }^{\circledR}$ - Limites de exposição ocupacional (TLVS $\left.{ }^{\circledR}\right)$ para substâncias químicas e agentes físicos \& índices biológicos de exposição (BEIs $\left.{ }^{\circledR}\right)$. São Paulo, tradução da Associação Brasileira de Higienistas Ocupacionais (ABHO), (atualização anual), 2008. 